\title{
圧挫により大腿動脈の皮下断裂をきたした一例
}

\author{
佐賀医科大学整形外科 \\ 上 通一泰・肥 後 たかみ \\ 園 畑 素 樹 - 釘 宮 基 泰 \\ 浅 見 昭 彦・佛 淵 孝 夫
}

\section{A Case of Subcutaneous Complete Rupture of Femoral Artery Caused by Collision}

\author{
Kazuyasu Uemichi, Takami Higo, Motoki Sonohata, \\ Motoyasu Kugimiya, Akihiko Asami, and Takao Hotokebuchi \\ Department of Orthopaedic Surgery, \\ Saga Medical School, Saga, Japan
}

\begin{abstract}
Although the arterial rupture of lower extremity is usually associated with fractures, the subcutaneous complete rupture of the artery is quite rare. This article discusses a 58-year-old man who was injured by collision against a concrete wall. On initial evaluation, he was noted to have blunt trauma of the left thigh with no fracture. Three hours after the injury, paresthesia and motor weakness were recognized in his lower leg. Angiography was therefore performed and it showed complete rupture of the femoral artery. At operation, an extensive hematoma was evacuated and femoropopliteal bypass graft was performed. Postoperative angiography showed sufficient blood flow in the grafted vein. Postoperative follow-up of the patient after 8 months showed no paresthesia or motor weakness in his left leg.
\end{abstract}

Key words : arterial rupture (血管損傷), Subcutaneous complete rupture (皮下完全断裂)

$$
\text { はじめに }
$$

今回我々は大腿部圧挫後に大腿動脈の皮下断裂をき たした極めて稀な症例を経験したので報告する。

$$
\text { 症例 }
$$

（症例） 58 歳, 男性

(主訴) 左大腿部痛

(現病歷) 平成 11 年 5 月 6 日, コンクリートブロッ クを一輪車で運搬中転倒。一輪車と石の塀との間に左 下肢を挟まれ受傷した。受傷より約 1 時間 30 分後に 救急車にて当院へ搬送された.

（既往歴）糖尿病，高血圧内服加療歷あり．ともにコ ントロールは良好であった。
(初診時身体所見) 左大腿の著明な腫脹・疼痛を認め た。また膝窝動脈・足背動脈の触知は不良で足部の冷 感も認められたが, 下肢の知覚・運動障害は認められ なかった。

(X 線写真) 明らかな骨傷は認められなかった.

(血液検査) $\mathrm{CPK}$ が $358 \mathrm{IU} / 1$ と軽度上昇している以 外，貧血等の異常所見は認められなかった。

大腿部の腫脹拉よび疼痛が強かった為, コンパート メント症候群を疑い, 入院となった。

（入院後経過）受傷約 4 時間後, 左下腿の知覚・運動 障害が急速に出現してきた為，直ちに血管造影を施行 した。

（術前血管造影所見）左大腿動脈の大腿中央部での途 絶像, 大腿深動脈の狭小化などの所見を認めた（図 1). 


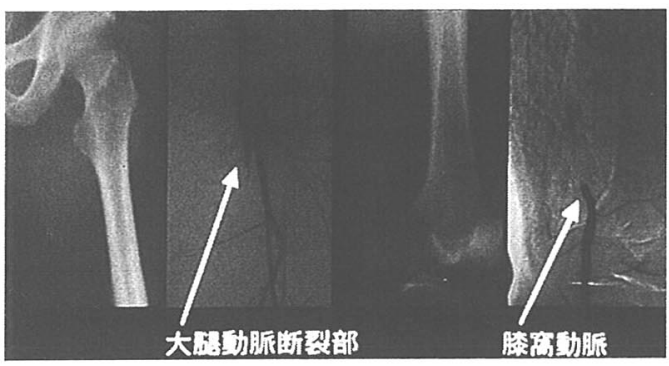

図 1 血管造影像 (受傷後 3 時間 30 分) 大腿動脈の途絶像が認められる。 䏚窩動脈は側副血行路により描出されている.

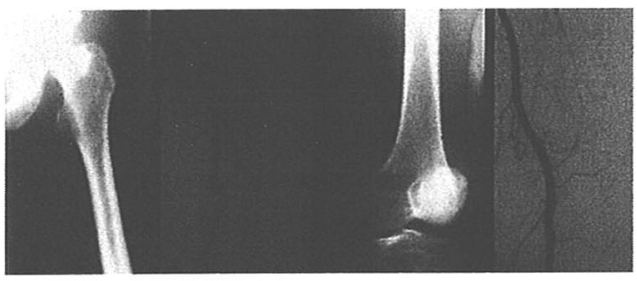

図 2 血管造影像（術後 13 日目） 静脈移植部の血行は良好である.

左大腿動脈完全断裂の診断にて, 同日緊急手術となっ た。

（術中所見）大腿動脈は大腿のほぼ中央部で完全断裂 していた。 また, 縫工筋・長内転筋の挫滅が認められ た. 断裂した大腿動脈に対し, 約 $10 \mathrm{~cm}$ の静脈移植を 行った。ドナーは健側の伏在静脈を使用した。 大腿静 脈に対しては結紫のみ行った。

(術後経過) 術直後から足背動脈の触知は良好になり, 左下腿以下の知覚・運動障害の軽減も認められた. 術 後 4 日目には知覚・運動障害はほぼ消失した.

術後 13 日目に施行した血管造影では静脈移植部の 開存は良好であった（図 2).

術後 8 力月現在, 下腿に軽度浮腫を認めるものの, 知覚・運動障害は全く認められていない.

\section{考察}

血管損傷の機序としては鈍的外力によるものと鋭的 外力によるものがある．正木ら ${ }^{2)}$ は，血管損傷を急性 型と慢性型に大きく分類し，受傷形態により，さらに 詳細に分類している（図 3）。この中で完全断裂は鋭



図 3 正木らによる血管損傷の形態分類 鈍的外力による血管損傷では false aneurysm や arteriovenous fistulaを形成し，慢性に経 過することが多いとしている.

的外力によるものが多く, 鈍的外力による受傷の場合 は血管が挫滅され慢性の経過を経て仮性動脈瘤や動静 脈瘻等が形成され，受傷期よりもかなりの時間を経て 初めて明らかになることが多いとしている.

また上道ら ${ }^{1)}$ は鈍的外力による非開放性血管損傷 15 症例を検討し, 非開放性の血管損傷においては通常, 強度な直達外力による圧挫傷が多く，その受傷形態は 血管の挫滅であると報告している。本症例では初診時, 我々は筋挫滅によるコンパートメント症候群を考え, 内圧測定や筋膜切開を念頭に置いていた。しかし，入 院後, 左下腿以下の知覚・運動障害の急速な出現を認 めたため，血管造影を行い，大腿動脈の完全断裂を発 見し, 受傷後早期に血行再建術を施行することができ た。本症例の経過から, 大腿動脈は入院時, 不全断裂 であったものが何らかの原因により完全断裂に移行し たものと推察された.つまり, 糖尿病, 高血圧の既往 があり，血管が脆弱な状態にあったところに鈍的外力 が加わり大腿動脈の不全断裂・筋挫滅が起こりコンパー トメント症候群が引き起こされた。その後大腿動脈は 完全断裂へと移行し，下腿の虚血症状として，足関節 以下の知覚・運動障害が急速に出現したと推察された.

結語

(1)鈍的外力により大腿動脈の皮下断裂を来した症例 を経験した。

(2)受傷後早期に血行再建術を施行し良好な結果を得 ることができた. 


\section{参考 文 献}

1）正木久男, 石田敦久: 四肢動静脈の損傷. 救急医学, 22 : 1089-1094, 1998.
2）上道 哲，柿木英佑：鈍的外力による非開放性四肢血 管損傷 15 例の経験. 日本臨床外科医学会雑誌, 52 巻增 刊: 360, 1991 . 